\title{
Porous structure of intercalated cobalt ferrocyanides
}

\author{
A. R. Tsyganov ${ }^{1}$, A. S. Panasugin ${ }^{2,}$, N.P. Masherova ${ }^{1}$, I. I. Kurilo ${ }^{1}$ \\ ${ }^{1}$ Belarusian State Technological University \\ ${ }^{2}$ Belarusian National Technical University
}

\begin{abstract}
Radiation safety is an integral part of environmental safety and includes a set of measures to protect people and the environment from the harmful effects of ionizing radiation. Ferrocyanides of transition metals are among the most highly effective and selective collectors for concentrating radionuclides. Under certain conditions of synthesis, ferrocyanide compounds can be formed having a layered structure, for example, the ferrocyanide $2 \mathrm{Co} 2[\mathrm{Fe}(\mathrm{CN}) 6] \mathrm{K} 4[\mathrm{Fe}(\mathrm{CN}) 6] 3 \mathrm{H} 2 \mathrm{O}$, however, taking into account the structure of the starting material it was decided to use $\mathrm{Fe} 3+$ polyhydroxy complexes as a modifying agent. The effect of the amount of modifiers on the sorption properties of cobalt ferrocyanide was studied in the course of the work.
\end{abstract}

\section{Introduction}

Radiation safety is an integral part of environmental safety and includes a set of measures to ensure the protection of humans and the environment from the harmful effects of ionizing radiation. Transition metal ferrocyanides are among the most highly efficient and selective collectors for the concentration of radionuclides [1-3].

Ferrocyanide crystals generally have a bulk or face-centered crystal lattice, and the porous structure is determined by the size of the crystallites and the way they are packaged. Under certain conditions of synthesis, ferrocyanide compounds can be formed having a layered structure, for example, the ferrocyanide $2 \mathrm{Co}_{2}\left[\mathrm{Fe}(\mathrm{CN})_{6}\right] \mathrm{K}_{4}\left[\mathrm{Fe}(\mathrm{CN})_{6}\right] 3 \mathrm{H}_{2} \mathrm{O}$, however, taking into account the structure of the starting material $\left(2 \mathrm{Co}_{2}\left[\mathrm{Fe}(\mathrm{CN})_{6}\right]\right.$ $\left.\mathrm{K}_{4}\left[\mathrm{Fe}(\mathrm{CN})_{6}\right] 3 \mathrm{H}_{2} \mathrm{O}\right)$ it was decided to use $\mathrm{Fe}^{3+}$ polyhydroxy complexes as a modifying agent.

Analysis of numerous literature data on intercalation systems containing a wide variety of matrices and "guest" molecules shows that the characteristic feature of the intercalation process in layered structures is the introduction of guest molecules into the interlayer space.

Interest in these processes is associated with the possibility of synthesizing new compounds with a complex of physicochemical properties, which are often difficult or impossible to obtain using traditional chemical methods of synthesis. Therefore, the search and creation of new intercalation systems (host matrix + "guests" molecules), the study of

*Corresponding author: niilogaz@tut.by 
the mechanism of formation and the identification of areas of their use are of undoubted scientific and practical interest.

Long-term practice shows that transition metal ferrocyanides are among the most highly efficient and selective collectors for concentrating radionuclides.

Ferrocyanide crystals generally have a bulk or face-centered crystal lattice, and the porous structure is determined by the size of the crystallites and the way they are packaged. Under certain conditions of synthesis, ferrocyanide compounds can be formed having a layered structure, for example, the ferrocyanide $2 \mathrm{Co}_{2}\left[\mathrm{Fe}(\mathrm{CN})_{6}\right] \mathrm{K}_{4}\left[\mathrm{Fe}(\mathrm{CN})_{6}\right] 3 \mathrm{H}_{2} \mathrm{O}$ [57,9]. Polyhydroxo complexes of polyvalent metals $\left(\mathrm{Al}^{3+}, \mathrm{Fe}^{3+}, \mathrm{Cr}^{3+}, \mathrm{Zr}^{4+}, \mathrm{La}^{3+}\right.$, etc. $)$ can act as intercalating compounds, however, taking into account the structure of the starting material $\left(2 \mathrm{Co}_{2}\left[\mathrm{Fe}(\mathrm{CN})_{6}\right] \mathrm{K}_{4}\left[\mathrm{Fe}(\mathrm{CN})_{6}\right] 3 \mathrm{H}_{2} \mathrm{O}\right)$ it was decided to use $\mathrm{Fe}^{3+}$ polyhydroxy complexes as a modifying agent.

The purpose of this work was to study the peculiarities of the formation of the porous structure of cobalt ferrocyanides $\left(2 \mathrm{Co}_{2}\left[\mathrm{Fe}(\mathrm{CN})_{6}\right] \cdot \mathrm{K}_{4}\left[\mathrm{Fe}(\mathrm{CN})_{6}\right] \cdot 3 \mathrm{H}_{2} \mathrm{O}\right)$ intercalated with iron (III) hydroxocomplexes.

Based on X-ray phase analysis, Mössbauer and IR spectroscopy, electron microscopy, and data on adsorption-structural analysis, a model for the formation of the porous structure of modified cobalt ferrocyanide has been proposed.

\section{Results and discussion}

The samples were examined by Mössbauer spectroscopy on a YAGRS-4m spectrometer with an AI-1024 multichannel analyzer. MICX - $3\left({ }^{57 m} \mathrm{Co}\right)$ was used as a source of gamma radiation. The measurement temperature is $273 \mathrm{~K}$. The density of the absorber was 20 $\mathrm{mg} / \mathrm{cm}^{2}$ for a natural mixture of iron isotopes. The spectrometer was calibrated using sodium nitroprusside. Isomeric shifts were given relative to sodium nitroprusside.

The quantitative values obtained during the experiments are shown in Table 1.

Table 1. Quantitative values obtained during the experiments

\begin{tabular}{|l|l|l|c|c|c|c|}
\hline \multirow{2}{*}{ Samples } & \multicolumn{2}{|c|}{$\mathrm{Fe}^{+2}\left(\mathrm{I}_{1}\right)$} & \multicolumn{3}{c|}{$\mathrm{Fe}^{+3}\left(\mathrm{I}_{2}\right)$} & \multirow{2}{*}{ Ratio $\mathrm{I}_{1} / \mathrm{I}_{2}$} \\
\cline { 2 - 6 } & $\mathrm{G}_{1}, \mathrm{Mm} / \mathrm{c}$ & $\mathrm{IC},(\delta) \mathrm{Mm} / \mathrm{c}$ & $\mathrm{G}_{2}, \mathrm{MM} / \mathrm{c}$ & $\mathrm{IC},(\delta) \mathrm{Mm} / \mathrm{c}$ & $\Delta \mathrm{E}, \mathrm{Mm} / \mathrm{c}$ & \\
\hline FeCNCo-ix & 0.45 & 0.17 & - & - & - & 0.0 \\
\hline FeCNCo-5 & 0.47 & 0.17 & 0.45 & 0.60 & 0.50 & 0.10 \\
\hline FeCNCo-10 & 0.51 & 0.17 & 0.47 & 0.62 & 0.58 & 1.75 \\
\hline FeCNCo-15 & 0.50 & 0.18 & 0.47 & 0.62 & 0.60 & 2.0 \\
\hline
\end{tabular}

$\mathrm{G}$ is the width of the Mössbauer line at half-height;

IC $(\delta)$ is the isomeric shift;

$\Delta$ - quadrupole splitting.

The results of processing the Mossbauer spectra of samples 2-4 showed the presence of three components of the spectrum: one singlet and two doublets indicates that as a result of modification, at least three different iron-containing compounds are present in samples 2-4. The main iron-containing component in the samples is $\mathrm{Co}_{2}\left[\mathrm{Fe}(\mathrm{CN})_{6}\right]$, as well as $\mathrm{Fe}_{4}\left[\mathrm{Fe}(\mathrm{CN})_{6}\right] 3$ and iron hydroxocomplexes, which is also confirmed by IR spectroscopy data.

On the IR spectrum of the initial sample of the FCCo-ix, there are lines in the frequency range of $600-605 \mathrm{~cm}^{-}$and $2090 \mathrm{~cm}^{-}$(group $\mathrm{C} \equiv \mathrm{N}$ ), characteristic of the compound $\mathrm{Co}_{2}\left[\mathrm{Fe}(\mathrm{CN})_{6}\right]$, the line $2042 \mathrm{~cm}^{-}$corresponds to the vibrational spectra of $\mathrm{K}_{4}\left[\mathrm{Fe}(\mathrm{CN})_{6}\right]$ $3 \mathrm{H}_{2} \mathrm{O}[9]$. 
The presence of responses in the region of $3620-3630 \mathrm{~cm}^{-}$and $3350-3420 \mathrm{~cm}^{-}$can be attributed, respectively, to the valence vibrations of water molecules and the valence vibrations of the $\mathrm{O}-\mathrm{H}$ bond of water molecules.

Vibrations of $1610 \mathrm{~cm}^{-}$correspond to the deformation vibrations of coordinated water molecules in the interlayer or intercrystalline space.

The presence of bands in the spectrum at $468-475 \mathrm{~cm}^{-}$is attributed to the valence vibrations of the $\mathrm{Co}-\mathrm{O}$ bond, and the vibrations in the region of $510-515 \mathrm{~cm}^{-}$are attributed to the bridge vibrations of the $\mathrm{HO}-\mathrm{Fe}$ bond [9].

As a result of processing the initial compound $2 \mathrm{Co}_{2}\left[\mathrm{Fe}(\mathrm{CN})_{6}\right] * \mathrm{~K}_{4}\left[\mathrm{Fe}(\mathrm{CN})_{6}\right] * 3 \mathrm{H}_{2} \mathrm{O}$ by iron (III) polyhydroxocomplexes, a noticeable shift of the vibrational spectra of the $\mathrm{C} \equiv \mathrm{N}$ group to a higher frequency region is observed. This fact is related to the fact that the interaction of iron (III) polyhydroxocomplexes with $2 \mathrm{Co}_{2}\left[\mathrm{Fe}(\mathrm{CN})_{6}\right] * \mathrm{~K}_{4}\left[\mathrm{Fe}(\mathrm{CN})_{6}\right] * 3 \mathrm{H}_{2} \mathrm{O}$ the compound is formed $\mathrm{Fe}_{4}\left[\mathrm{Fe}(\mathrm{CN})_{6}\right]_{3}$. This interaction is accompanied by the disappearance of the $2042 \mathrm{~cm}^{-}$band corresponding to the vibrational spectra of the $\mathrm{C} \equiv \mathrm{N}$ group of potassium (II) ferrocyanide $\mathrm{K}_{4}\left[\mathrm{Fe}(\mathrm{CN})_{6}\right] 3 \mathrm{H}_{2} \mathrm{O}$, and the appearance of the band $2075 \mathrm{~cm}^{-}$, related to the compound $\mathrm{Co}_{2}\left[\mathrm{Fe}(\mathrm{CN})_{6}\right]$ and bands corresponding to the vibrations of the group $\mathrm{C} \equiv \mathrm{N}$ of the compound $\mathrm{Fe}_{4}\left[\mathrm{Fe}(\mathrm{CN})_{6}\right]_{3}$ [9], which shift from 2085 to $2110 \mathrm{~cm}^{-}$as the amount of the modifying agent increases

The IR spectra of the modified samples show an increase in the intensity of the absorption lines of the strain vibrations of the coordinated water molecules in the interlayer at $1610 \mathrm{~cm}$ and the valence vibrations of the $\mathrm{O}-\mathrm{H}$ bond of water molecules at 3350-3420 $\mathrm{cm}^{-}$compared to the FCCo-ix. This is due to the fact that the hydroxyl groups of iron (III) hydroxocomplexes contribute to the increase in the intensity of these oscillations.

The data of the X-ray phase analysis are presented in Fig. 1 and in Table 2.

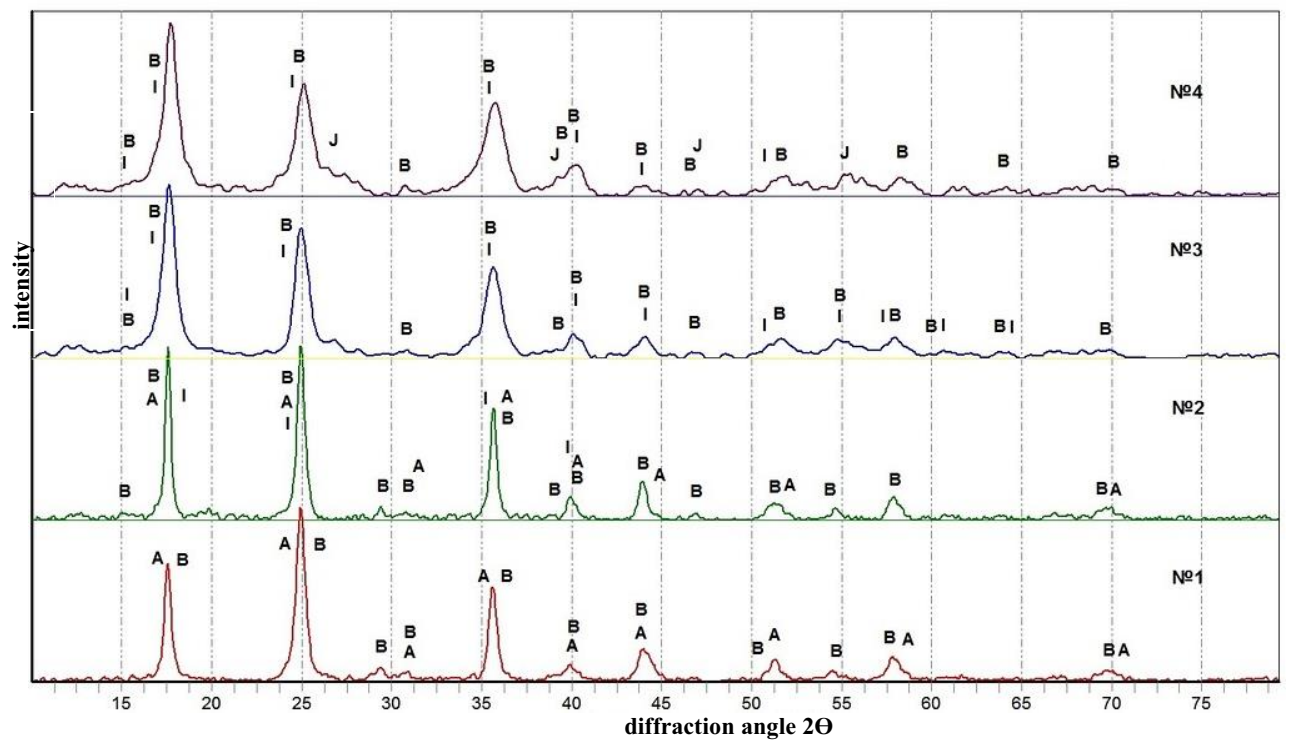

Fig. 1. Radiographs of the initial sample of the FCCo-ix. ((1) and modified samples of FCCo-5 (2), of FCCo -10 (3), of FCCo -15 (4). 
Table 2 Crystal phases of the samples.

\begin{tabular}{|c|c|c|c|}
\hline Samples, № & Samples & Phase designation & Phase \\
\hline 1 & FCCo -ix & $\mathrm{A}$ & $\mathrm{K}_{4}\left[\mathrm{Fe}(\mathrm{CN})_{6}\right]$ \\
\cline { 3 - 4 } & & $\mathrm{B}$ & $\mathrm{Co}_{2}\left[\mathrm{Fe}(\mathrm{CN})_{6}\right]$ \\
\hline 2 & \multirow{2}{*}{ FCCo -5 } & $\mathrm{A}$ & $\mathrm{K}_{4}\left[\mathrm{Fe}(\mathrm{CN})_{6}\right]$ \\
\cline { 3 - 4 } & & $\mathrm{B}$ & $\mathrm{Co}_{2}\left[\mathrm{Fe}(\mathrm{CN})_{6}\right]$ \\
\cline { 3 - 4 } & & $\mathrm{I}$ & $\mathrm{Fe}_{4}\left[\mathrm{Fe}(\mathrm{CN})_{6}\right]_{3}$ \\
\hline \multirow{2}{*}{3} & FCCo -10 & $\mathrm{B}$ & $\mathrm{Co}_{2}\left[\mathrm{Fe}(\mathrm{CN})_{6}\right]$ \\
\cline { 3 - 4 } & & $\mathrm{I}$ & $\mathrm{Fe}_{4}\left[\mathrm{Fe}(\mathrm{CN})_{6}\right]_{3}$ \\
\hline \multirow{2}{*}{4} & FCCo -15 & $\mathrm{B}$ & $\mathrm{Co}_{2}\left[\mathrm{Fe}(\mathrm{CN})_{6}\right]$ \\
\cline { 3 - 4 } & & $\mathrm{I}$ & $\mathrm{Fe}_{4}\left[\mathrm{Fe}(\mathrm{CN})_{6}\right]_{3}$ \\
\cline { 3 - 4 } & & $\mathrm{J}$ & $\mathrm{Fe}_{2} \mathrm{O}_{3} \cdot \mathrm{H}_{2} \mathrm{O}$ \\
\hline
\end{tabular}

X-ray phase analysis data show that the untreated sample of the FCCo - ix it is a compound $2 \mathrm{Co}_{2}\left[\mathrm{Fe}(\mathrm{CN})_{6}\right] \quad \mathrm{K}_{4}\left[\mathrm{Fe}(\mathrm{CN})_{6}\right] \quad 3 \mathrm{H}_{2} \mathrm{O}$. After the introduction of iron (III) hydroxocomplexes, the phase disappears $\mathrm{K}_{4}\left[\mathrm{Fe}(\mathrm{CN})_{6}\right]$ and the crystal phase of $\mathrm{Fe}_{4}\left[\mathrm{Fe}(\mathrm{CN})_{6}\right]_{3}$ appears, which indicates an interaction between iron (III) hydroxocomplexes and potassium ferrocyanide.

Electron microscopy data indicate that during the modification of the initial cobalt ferrocyanide, a more branched structure of the sorption material is formed.

This assumption is confirmed by the fact that for all modified samples, an increase in the values of the specific surface area and sorption volumes is observed. If for the initial sample (FCCo-ix) $\mathrm{S}_{\text {ud. }}=64 \mathrm{~m}^{2} / \mathrm{g}$ and $\mathrm{Vs}=0.132 \mathrm{~cm}^{3} / \mathrm{g}$, then for samples modified with hydroxocomplexes in the amount of $5 \mathrm{mmol} \mathrm{Fe}^{3+}$ per gram of the sample, they are respectively $131 \mathrm{~m}^{2} / \mathrm{g}$ and $0.2 \mathrm{~cm}^{3} / \mathrm{g}$. With an increase in the amount of modifying agent, the surface area significantly increases to $170 \mathrm{~m}^{2} / \mathrm{g}$, the sorption volume increases slightly [7]

Based on the above, the following mechanism of formation of the porous structure of modified materials is presented to us.

Figure 2 shows the general scheme of the modification process $2 \mathrm{Co}_{2}\left[\mathrm{Fe}(\mathrm{CN})_{6}\right] \mathrm{K}_{4}\left[\mathrm{Fe}(\mathrm{CN})_{6}\right] 3 \mathrm{H}_{2} \mathrm{O}$ by $\mathrm{Fe}_{\mathrm{x}}(\mathrm{OH})_{4 \mathrm{x}} \mathrm{Fe}_{\mathrm{x}}$ hydroxocomplexes. 


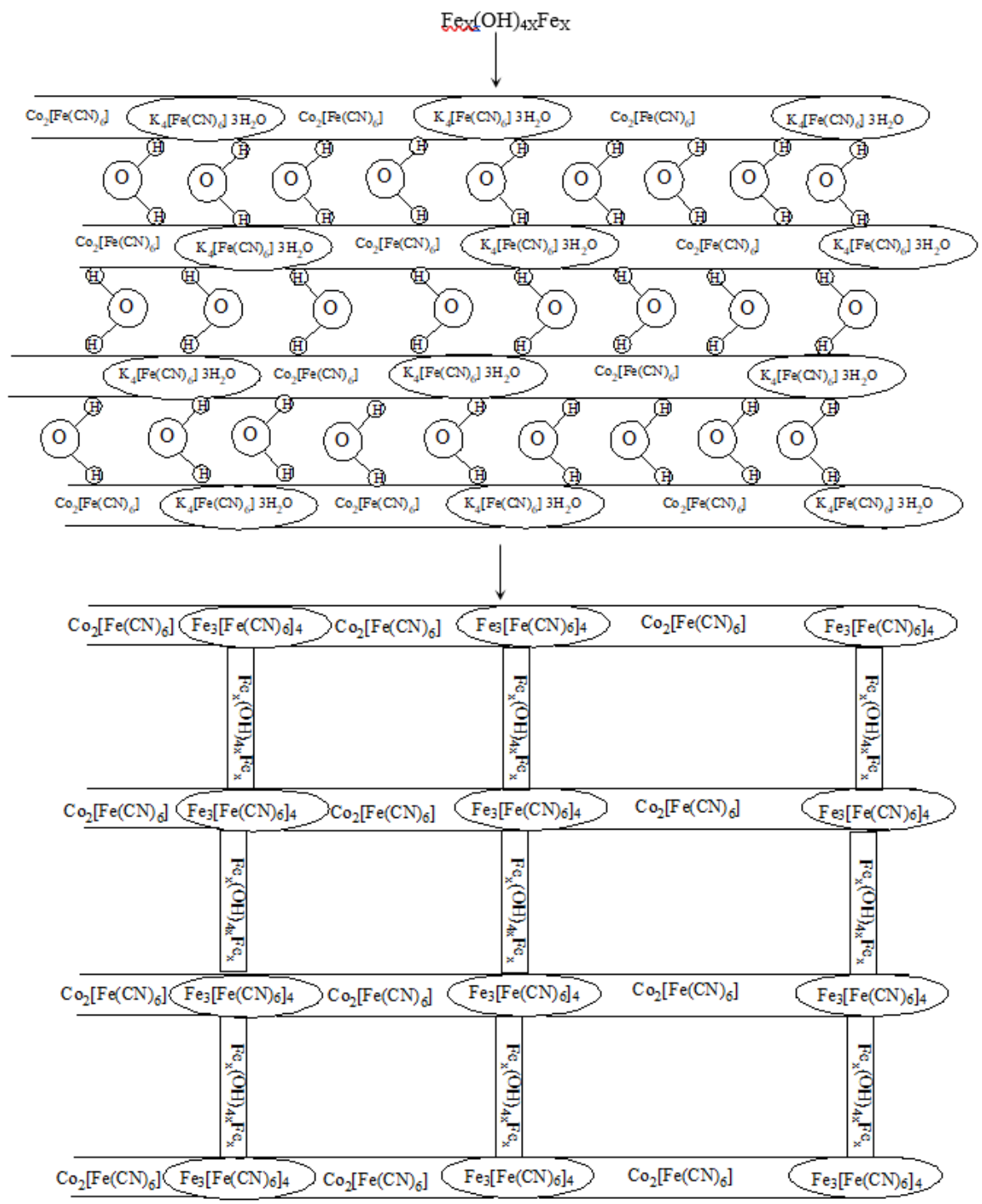

Fig. 2. General scheme of the modification process $2 \mathrm{Co} 2[\mathrm{Fe}(\mathrm{CN}) 6] \cdot \mathrm{K} 4[\mathrm{Fe}(\mathrm{CN}) 6] \cdot 3 \mathrm{H} 2 \mathrm{O}$ by $\mathrm{Fex}(\mathrm{OH}) 4 \mathrm{xFex}$ hydroxocomplexes.

Figure 3 shows a general scheme of the formation of the porous structure of samples when modifying $2 \mathrm{Co}_{2}\left[\mathrm{Fe}(\mathrm{CN})_{6}\right] \cdot \mathrm{K}_{4}\left[\mathrm{Fe}(\mathrm{CN})_{6}\right] \cdot 3 \mathrm{H}_{2} \mathrm{O}$ by $\mathrm{Fe}_{\mathrm{x}}(\mathrm{OH})_{4 \mathrm{x}} \mathrm{Fe}_{\mathrm{x}}$ hydroxocomplexes. 


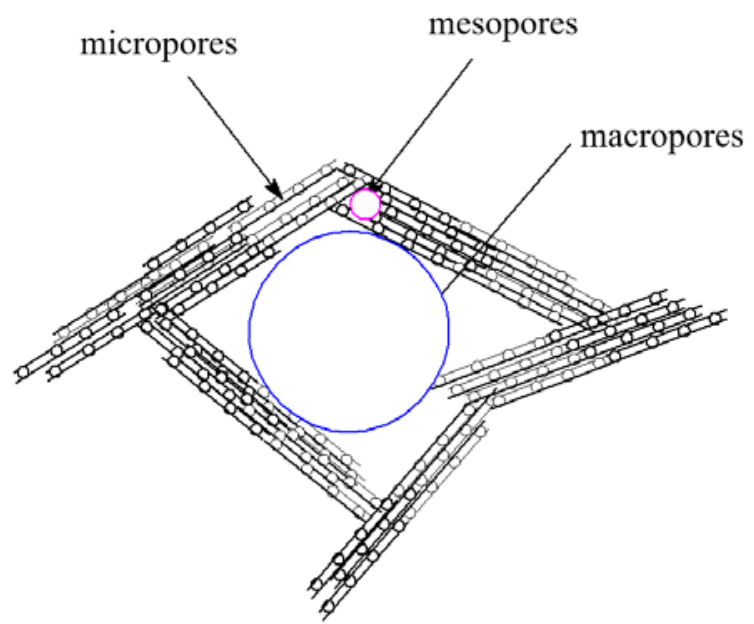

Fig. 3. Scheme of formation of the porous structure of samples during modification of $2 \mathrm{Co}_{2}\left[\mathrm{Fe}(\mathrm{CN})_{6}\right] \mathrm{K}_{4}\left[\mathrm{Fe}(\mathrm{CN})_{6}\right] 3 \mathrm{H}_{2} \mathrm{O}$ by $\mathrm{Fe}_{\mathrm{x}}(\mathrm{OH})_{4 \times} \mathrm{Fe}_{\mathrm{x}}$ hydroxocomplexes

Further, the variants of the modification process $2 \mathrm{Co}_{2}\left[\mathrm{Fe}(\mathrm{CN})_{6}\right] \mathrm{K}_{4}\left[\mathrm{Fe}(\mathrm{CN})_{6}\right] 3 \mathrm{H}_{2} \mathrm{O}$ by $\mathrm{Fe}(\mathrm{OH})_{4 \mathrm{x}} \mathrm{Fe}_{\mathrm{x}}$ hydroxocomplexes, shown in Fig4.

a

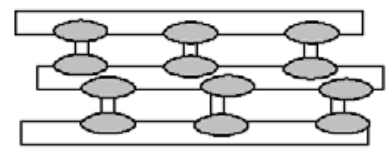

c
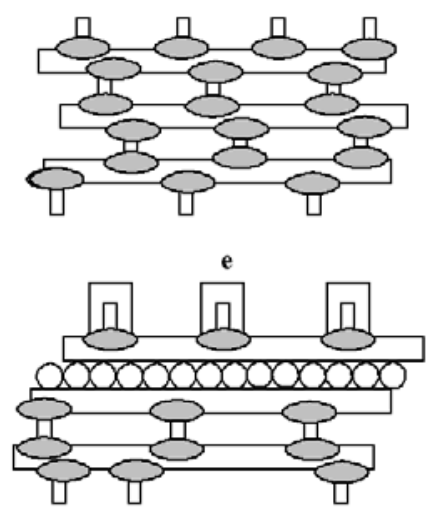

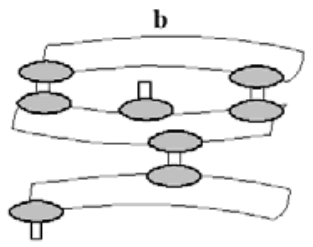

d

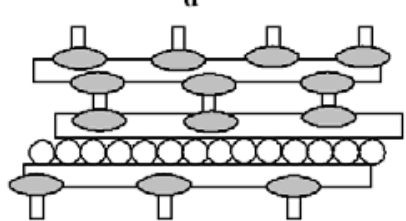

Symbols

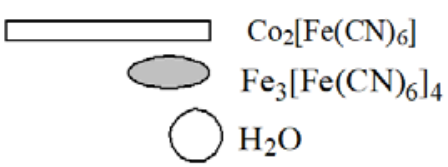

$\mathrm{C} \mathrm{Fe}_{\mathrm{x}}(\mathrm{OH})_{4 \mathrm{x}} \mathrm{Fe}_{\mathrm{x}}$

(1) $\mathrm{Fe}_{\mathrm{X}}(\mathrm{OH})_{4 \mathrm{X}} \mathrm{Fe}_{\mathrm{e}} \mathrm{n}$

Fig 4. Variants of the modification process $2 \mathrm{Co}_{2}\left[\mathrm{Fe}(\mathrm{CN})_{6}\right] \mathrm{K}_{4}\left[\mathrm{Fe}(\mathrm{CN})_{6}\right] 3 \mathrm{H}_{2} \mathrm{O}$ by $\mathrm{Fe}(\mathrm{OH})_{4 \times \mathrm{Fex}}$ hydroxocomplexes 
Commenting on the variants of the modification process $2 \mathrm{Co}_{2}\left[\mathrm{Fe}(\mathrm{CN})_{6}\right] \mathrm{K}_{4}[\mathrm{Fe}(\mathrm{CN}) 6] 3 \mathrm{H}_{2} \mathrm{O}$ by $\mathrm{Fe}_{\mathrm{x}}(\mathrm{OH})_{4 \mathrm{x}} \mathrm{Fe}_{\mathrm{x}}$ hydroxocomplexes, the following can be stated $\boldsymbol{a}$ - case a is the ideal case of the process of modification of $2 \mathrm{Co}_{2}\left[\mathrm{Fe}(\mathrm{CN})_{6}\right] \mathrm{K}_{4}\left[\mathrm{Fe}(\mathrm{CN})_{6}\right] 3 \mathrm{H}_{2} \mathrm{O}$ by $\mathrm{Fe}_{\mathrm{x}}(\mathrm{OH})_{4 \mathrm{x}} \mathrm{Fe}_{\mathrm{x}}$ hydroxocomplexes; case $\boldsymbol{b}$ - formation of deformed layers of $\mathrm{Co}_{2}\left[\mathrm{Fe}(\mathrm{CN})_{6}\right]$; $\boldsymbol{c}$-formation on the surface of layers of $\mathrm{Co}_{2}\left[\mathrm{Fe}(\mathrm{CN})_{6}\right]$ of the $\mathrm{Fe}_{\mathrm{x}}(\mathrm{OH})_{4 \mathrm{x}} \mathrm{Fe}_{\mathrm{x}}$ layer; $\boldsymbol{d}$ - is not a complete modification process of $2 \mathrm{Co}_{2}\left[\mathrm{Fe}(\mathrm{CN})_{6}\right] \mathrm{K}_{4}\left[\mathrm{Fe}(\mathrm{CN})_{6}\right] 3 \mathrm{H}_{2} \mathrm{O}$ by $\mathrm{Fe}_{\mathrm{x}}(\mathrm{OH})_{4 \mathrm{x}} \mathrm{Fe}_{\mathrm{x}}$ hydroxocomplexes; $\boldsymbol{e}$ - incomplete modification process of $2 \mathrm{Co}_{2}\left[\mathrm{Fe}(\mathrm{CN})_{6}\right] \mathrm{K}_{4}\left[\mathrm{Fe}(\mathrm{CN})_{6}\right] 3 \mathrm{H}_{2} \mathrm{O}$ by $\mathrm{Fe}_{\mathrm{x}}(\mathrm{OH})_{4 \mathrm{x}} \mathrm{Fe}_{\mathrm{x}}$ hydroxocomplexes with the formation of layers on the surface $\mathrm{Co}_{2}\left[\mathrm{Fe}(\mathrm{CN})_{6}\right]$ micro porous agglomerates $\left[\mathrm{Fe}_{\mathrm{x}}(\mathrm{OH})_{4 \mathrm{x}} \mathrm{Fe}_{\mathrm{x}}\right]_{\mathrm{n}}$ formed by $\mathrm{Fe}_{\mathrm{x}}(\mathrm{OH})_{4 \mathrm{x}} \mathrm{Fe}_{\mathrm{x}}$.

\section{Conclusion}

Thus, based on the data of adsorption-structural measurements, X-ray phase analysis and IR spectroscopy, it can be assumed that iron (III) hydroxo-complexes enter the intercrystalline space of the FCCo-ex, as a result of which the $\mathrm{Fe}_{4}\left[\mathrm{Fe}(\mathrm{CN})_{6}\right]_{3}$ compound is formed at the boundaries of the FCCo-ex crystallites and a porous structure with large specific surface area and sorption volume is formed.

\section{References}

1. Yu. V.Kuznetsov, V. N.Schebetkovsky, A. G. Trusov, Fundamentals of water purification from radioactive contamination, (Atomizdat Publ, Moscow, 1974) [in Russian]

2. J. A. Berry, J. Radiochimica Acta, 44-45, 135-141 (1988)

3. V. Vesely, V. Pekarek, Talanta, 19(3), 248-1253, (1972)

4. A. Grütter, H. R. von Gunter, E. Rössler, R. Keil, J. Radiochimica Acta, 64, 247-252 (1994)

5. V. S. Komarov, A. I. Ratko, A. S. Panasugin, N. Ye. Trofimenko, N. P. Masherova, S. V. Stesik, Bulleten of the Academy of Sciences of BSSR. Series of Chemical Sciences, 5, 1991, 20-24 (in Russian).

6. V. S. Komarov, A. I. Ratko, A. S. Panasugin, N. Ye. Trofimenko, N. P. Masherova Bulleten of the Academy of Sciences of BSSR. Series of Chemical Sciences, 2, 8-12. (1992), (In Russian).

7. A. S. Panasugin, G. V. Bondareva, N. V. Kitikova, O. V. Strukova, Colloid J., 3, 520523 (2003) no. (In Russian).

8. S. Greg, K. Singh, Adsorption, specific surface, porosity (Mir Publ., Moscow, 1984)

9. I. V. Tananaev, G. B. Seyfer, Yu. Ya. Kharitonov, V. G. Kuznetsov, Chemisfry of ferrocyanides, (Nauka Publ., Moscow, 1971 